\title{
Searching for genes of interest in Sheep
}

\author{
Carole R. Moreno ${ }^{1 \dagger}$, Jean-Michel Elsen ${ }^{1}$, Andrès Legarra ${ }^{1}$, Rachel Rupp ${ }^{1}$, J. Bouix ${ }^{1}$, \\ François Barillet ${ }^{1}$, Isabelle Palhiere ${ }^{1}$, Hélène Larroque ${ }^{1}$, Daniel Allain ${ }^{1}$, Dominique Francois ${ }^{1}$, \\ Christele Robert ${ }^{1}$, Gwenola Tosser-Klopp ${ }^{2}$, Loys Bodin ${ }^{1}$ and Philippe Mulsant ${ }^{2}$
}

${ }^{1}$ INRA, UR631, Station d'Amélioration Génétique des Animaux, F-31320 Castanet-Tolosan, France; ${ }^{2}$ UMR 444 INRA-ENVT-Génétique cellulaire, F-31320 CastanetTolosan, France

In the past, several studies have been performed to look for genes affecting traits of interest using microsatellite markers in sheep. Even if numerous chromosomal regions have been detected, few genes and causal mutations have been identified. The recent availability of high density SNP chips in sheep is a technological revolution for genomic research and breeding selection.

Firstly, genomic research in small ruminants will be boosted towards the identification of causative mutations underlying large genetic effects on sustainability traits, or the identification of very closely linked genetic markers that allow selecting genes in sheep. Even if this strategy needs a large investment to detect causal mutation, the gene selection allows to select trait (1) without phenotyping which is particularly suitable for traits difficult to measure such as disease resistance, (2) whatever the population size (at the farm or the breed level) (3) without expensive genotyping. Because of these three advantages, when mutations are available, the gene selection is really adapted to selection in developing countries. However, be careful to select only one gene, mainly for disease resistance which is a real important trait in tropical areas. In fact, the breakdown of resistance by the pathogen could be observed in such conditions. To escape this problem, the selection of a major gene could be associated to chemical treatment or, in the best way, to the selection of other genes affecting the same trait.

Secondly, such new molecular tools allow considering a new type of selection: the genomic selection. The principle of this selection is to use marker effects (without any information about the underlying genes) estimated within a part of the population which is phenotyped and genotyped (called the training population) and applying these effects to the rest of the genotyped population. However, the genomic selection might not always be a profitable strategy in sheep, particularly in developing countries. In fact, it is necessary to produce several thousands of individuals in the training population in order to estimate correctly the marker effects. Moreover, this population has to be generally selected within breed except when the commercial population is a mixture of several close breeds in terms of evolution. So the production of the training population is really difficult to produce particularly in small breeds.

${ }^{\dagger}$ E-mail: carole.moreno@toulouse.inra.fr

\section{Characterization and importance of pig breeds in the pork industry of the Bobo-Dioulasso zone (Burkina Faso, West Africa)}

\author{
Timbilfou Kiendrebeogo ${ }^{1+}$, Y. Mopate Logtene ${ }^{2}$, S. R. Kondombo ${ }^{1}$ and \\ C. Y. Kabore-Zoungrana ${ }^{3}$
}

\begin{abstract}
${ }^{1}$ Institut de I'Environnement et de recherches Agricoles (INERA), Département Productions Animales (PA)/Programme Monogastrique, Station de Kambouinsé, BP. 476 Ouagadougou, Burkina Faso; 'Laboratoire de Recherches Vétérinaires et Zootechnique de Djaména, BP 433, N'Djaména, Tchad. Chercheur associé au LERNSE de I'Université Polytechnique de Bobo-Dioulasso; ${ }^{3}$ Laboratoire d'Etudes et de recherches sur les Ressources Naturelles et les Sciences de I'Environnement (LERNSE), Université polytechnique de Bobo-dioulasso (UPB), 01B.P.1091 Bobo-Dioulasso 01 Burkina Faso
\end{abstract}

Porcine breeding is dominant in Burkina Faso in comparison with pig number (1886 234 pigs) (MED/MRA, 2004), with an increase of 20.6\%/ year. But its contribution to the meat supply of the population is weak (approximately 10\% between 1993 and 2003). The Haut-Bassins whose main city is Bobo-Dioulasso is classified 4 th/13 regions with approximately $12 \%$ of porcine pig number. To characterize and evaluate the importance of pig breeds in the pork industry of this zone, the data from an investigation diagnosis of breeding systems (2003) and from an investigation into the supply pig meat of the town of Bobo-Dioulasso (2005) were analyzed. Three main pig breeds (Korhogo, local breed

\footnotetext{
${ }^{\dagger}$ E-mail: timbilfou@gmail.com
} 